\title{
AS FUNÇÕES FIGURATIVAS DO COMENTÁRIO METADISCURSIVO EM DEBATES ELEITORAIS
}

(The figurative functions of the metadiscourse commentary in electoral debates)

\author{
Gustavo Ximenes Cunha ${ }^{1}$ \\ (Universidade Federal de Minas Gerais) \\ Paloma Bernardino Braga ${ }^{2}$ \\ (Universidade Federal de Minas Gerais) \\ Daniel Martins de Brito ${ }^{3}$ \\ (Universidade Federal de Minas Gerais)
}

\begin{abstract}
RESUMO
Este trabalho investiga, numa perspectiva interacionista dos estudos do discurso, as funções que a relação de comentário metadiscursivo (CM) exerce no processo de figuração entre candidatos participantes de dois debates eleitorais. Partindo de pesquisa previamente realizada sobre o CM, caracterizamos os CMs do corpus em termos de seu potencial para o ataque e para a defesa das faces construídas conjuntamente nos debates. Verificamos que essa relação de discurso auxilia cada candidato a desempenhar uma linha de conduta tensa, dosando constantemente a intensidade dos ataques e das defesas que realiza em relação às faces em jogo.
\end{abstract}

Palavras-chave: Comentário metadiscursivo. Debate eleitoral. Processo de figuração.

\section{ABSTRACT}

This work, which adopts an interactionist perspective of discourse studies, investigates the functions of the metadiscourse commentary (CM) in the face work done by the politicians protagonists of two electoral debates. Based on previous research on the CM, we characterize the CMs of the corpus in terms of their potential for attack and defense of the faces constructed together in the debates. As evidenced by the results, by using this discourse relation, each candidate is able to play a tense line of behavior, with which he constantly measures the intensity of attacks and defenses against faces.

Keywords: Metadiscourse commentary. Electoral debates. Face work.

\section{RESUMEN}

Este trabajo investiga, desde una perspectiva interaccionista de los estudios del discurso, las funciones de la relación de comentario metadiscursivo (CM) en el proceso de figuración entre los candidatos que participan en dos debates electorales. Con base en investigaciones realizadas anteriormente sobre el CM, caracterizamos los CM del corpus en términos de su potencial de ataque y de defensa de imágenes construidas conjuntamente en los debates. Descubrimos que esta relación de discurso ayuda a cada candidato a realizar una línea de conducta tensa, evaluando

\footnotetext{
${ }^{1}$ Professor da Faculdade de Letras (UFMG) e do Programa de Pós-Graduação em Estudos Linguísticos (UFMG) e membro do Grupo de Estudos sobre Pragmática, Texto e Discurso (GEPTED/CNPq). E-mail: ximenescunha@yahoo.com.br. ORCID: https://orcid.org/0000-0001-9953-1204.

${ }^{2}$ Graduanda em Letras pela UFMG, membro do Grupo de Estudos sobre Pragmática, Texto e Discurso (GEPTED/CNPq) e integrante de projeto de pesquisa, na modalidade Iniciação Científica Voluntária, vinculado à Pró-Reitoria de Pesquisa da UFMG. E-mail: palomabbraga@gmail.com. ORCID: https://orcid.org/0000-0002-1875$\underline{9774}$.

${ }^{3}$ Graduando em Letras pela UFMG, membro do Grupo de Estudos sobre Pragmática, Texto e Discurso (GEPTED/CNPq) e integrante de projeto de pesquisa, na modalidade Iniciação Científica Voluntária, vinculado à Pró-Reitoria de Pesquisa da UFMG. E-mail: danielmrtinsb@gmail.com. ORCID: https://orcid.org/0000-0002-1942$\underline{153 X}$.
} 
constantemente la intensidad de los ataques y las defensas que realiza en relación con las imágenes en juego.

Palabras clave: Comentario metadiscursivo. Debate electoral. Proceso de figuración.

Recebido em: maio 2019

Aceito em: dezembro 2019

DOI: $\underline{10.26512 / \text { les.v20i2.24445 }}$

\section{INTRODUÇÃO}

Este trabalho tem como finalidade investigar as funções que uma relação de discurso específica, a relação de comentário metadiscursivo $(\mathrm{CM})$, exerce no desenvolvimento do processo de figuração (face work (GOFFMAN, 1967[1955])) entre candidatos participantes de debates eleitorais. Tradicionalmente, os estudos sobre processo de figuração, sobretudo aqueles inseridos no campo das teorias da im/polidez (cf. CULPEPER; TERKOURAFI, 2017), tomam o ato de fala como unidade de análise e, por isso, se centram no papel que nesse processo exercem elementos microlinguísticos (lexicais e gramaticais), como construções sintáticas, tempos verbais, advérbios e pronomes. Com o estudo das funções da relação de CM no processo de figuração em debates eleitorais, nosso intuito é revelar que não só elementos dessa natureza, mas também as relações de discurso $^{4}$ desempenham papel importante no modo como os interactantes negociam imagens identitárias (CUNHA, 2015, 2017a, 2019).

O presente trabalho constitui o desenvolvimento de pesquisa cuja finalidade consistiu em propor uma definição da própria noção de comentário metadiscursivo. Como os procedimentos de análise e os resultados dessa pesquisa, relatada em Cunha e Braga (2018), constituem o ponto de partida da presente proposta, eles serão brevemente recapitulados nesta introdução. Em Cunha e Braga (2018), procedemos à definição dessa noção com base em uma abordagem cognitivointeracionista da Análise do Discurso, o Modelo de Análise Modular do Discurso (ROULET; FILLIETTAZ; GROBET, 2001). Essa definição se baseou no estudo de um corpus formado por

\footnotetext{
${ }^{4}$ Conforme a abordagem de Roulet para o estudo da organização do discurso (2002, 2006, ROULET; FILLIETTAZ; GROBET, 2001), as relações de discurso são as relações que ligam um constituinte do texto (troca, intervenção ou ato) a uma informação previamente estocada na memória discursiva (conhecimentos partilhados pelos interactantes). Nessa abordagem, as relações são de dois tipos: ilocucionárias e interativas. São ilocucionárias as relações que ligam os constituintes da troca (ex.: pergunta, pedido, resposta etc.), e são interativas as relações que ligam os constituintes da intervenção (ex.: comentário, argumento, reformulação etc.).
} 
dois debates eleitorais ${ }^{5}$ e seguiu algumas etapas de análise, que apresentaremos sumariamente a seguir.

Inicialmente, estudamos o gênero debate eleitoral. Por meio da articulação de propriedades situacionais do debate, tais como finalidade geral (apresentação de pontos de vista antagônicos sobre assuntos de interesse público), participantes (adversários, plateia e mediador) e linguagem característica (uso de linguagem verbal agressiva), foi possível entendê-lo como um gênero que "se define por colocar em cena candidatos a cargos políticos que exibem visões divergentes e antagônicas do mundo social, contribuindo para a construção de uma polarização bastante marcada na maneira de compreender tópicos de interesse da população" (CUNHA; BRAGA, 2018, p. 174). Em seguida, identificamos todas as ocorrências das relações de comentário presentes nos debates eleitorais estudados ${ }^{6}$. Nessa etapa, foi identificado um total de 265 relações de comentário: 114 (43\%) no debate entre Fernando Haddad e José Serra e 151 (57\%) no debate entre Dilma Rousseff e Aécio Neves.

Na sequência, extraímos, do conjunto dos comentários identificados na etapa precedente, aqueles que retomam (representam, citam, pressupõem, polemizam com) o discurso de diferentes instâncias enunciativas: o próprio candidato, o adversário ou terceiros. Essa retomada ocorreu em $121(45 \%)$ das 265 relações de comentário. Porque esses comentários representam o discurso de outras instâncias, eles constituem segmentos de discursos representados (ROULET; FILLIETTAZ; GROBET, 2001). Os segmentos de discursos representados, sejam eles autofônicos, diafônicos ou polifônicos ${ }^{7}$, possuem uma natureza metadiscursiva, na medida em que recaem sobre a ação de dizer (a enunciação) e não apenas sobre o dito (o enunciado) (DUCROT, 1987, PERRIN, 2004). Por isso, esses 121 comentários foram considerados metadiscursivos ${ }^{8}$. Com base na instância cujo

\footnotetext{
${ }^{5} \mathrm{O}$ primeiro foi o último debate da campanha pela prefeitura de São Paulo em 2012, do qual participaram Fernando Haddad (PT) e José Serra (PSDB). O debate pode ser acessado em: <http://www1.folha.uol.com.br/poder/1176189leia-a-transcricao-do-debate-da-tv-globo-entre-candidatos-a-prefeito-de-sp.shtml >. O segundo debate foi o último da campanha presidencial de 2014, do qual participaram Dilma Rousseff (PT) e Aécio Neves (PSDB). O debate pode ser acessado em: <http://g1.globo.com/politica/eleicoes/2014/transcricao-debate-presidencial-2-turno.html〉. Ambos os debates foram promovidos pelo mesmo veículo de comunicação, a Rede Globo.

6 “A relação de comentário articula um constituinte subordinado (o comentário) a uma informação previamente estocada na memória discursiva (o alvo do comentário ou aquilo que o locutor comenta)" (CUNHA; BRAGA, 2018, p. 176).

7 “O segmento de discurso é autofônico, se nele o locutor representa seu próprio discurso. O segmento de discurso é diafônico, se nele o locutor representa o discurso de seu interlocutor direto, aquele com quem o locutor compartilha o mesmo nível interacional. O segmento de discurso é polifônico, se nele o locutor representa o discurso de instâncias localizadas em outros níveis interacionais (o discurso de personagens, por exemplo)." (CUNHA; BRAGA, 2018 , p. 179.)

${ }^{8}$ Foram identificados 52 CMs (42\%) no debate entre Fernando Haddad e José Serra e 69 CMs (58\%) no debate entre Dilma Rousseff e Aécio Neves.
} 
discurso é representado no comentário, foi possível obter três tipos de CMs (CUNHA; BRAGA, 2018, p. 181):

1) Comentário metadiscursivo autofônico: o locutor avalia negativa ou positivamente seu próprio comportamento linguageiro ao longo do debate ou mesmo ao longo da campanha eleitoral.

2) Comentário metadiscursivo diafônico: o locutor avalia negativa ou positivamente o comportamento linguageiro do interlocutor (adversário ou integrante da plateia).

3) Comentário metadiscursivo polifônico: o locutor avalia negativa ou positivamente o comportamento linguageiro de terceiros (correligionários, assessores, o programa político etc).

Ao final do percurso de análise, realizamos um estudo preliminar das funções figurativas 9 que o CM exerce nos debates estudados. Com esse estudo, verificou-se que o CM é um recurso particularmente adequado para desqualificar ou desmerecer a visão de mundo e as propostas do oponente. Verificou-se também, embora de modo apenas aproximativo, que cada tipo de CM exerce funções mais específicas. Ao estabelecer essa relação de discurso, um candidato pode i) construir uma autoimagem favorável para si, reivindicando valores sociais positivos, como honestidade, competência ou idoneidade (CM autofônico); ii) desqualificar o adversário, retomando e reinterpretando sua fala conforme seus próprios interesses (CM diafônico); iii) desacreditar as ideias de terceiros e defender que as ideias do adversário, relegado ao estatuto de $3^{\text {a }}$ pessoa, são inapropriadas ou desprovidas de interesse (CM polifônico) (CUNHA; BRAGA, 2018).

Ao final dessas etapas relatadas em Cunha e Braga (2018, p. 185), foi possível obter esta definição para a noção de comentário metadiscursivo:

relação de discurso por meio da qual o locutor emprega um segmento de discurso representado para comentar, avaliando, uma informação da memória discursiva cuja origem é o comportamento linguageiro do próprio locutor (comentário metadiscursivo autofônico), do interlocutor (comentário metadiscursivo diafônico) ou de terceiro (comentário metadiscursivo polifônico).

Ainda que, como exposto, a pesquisa tenha apontado algumas funções dos CMs, as funções a que chegamos ao final do percurso de análise ofereceram mais caminhos para novas pesquisas do que resultados concretos sobre o papel que os CMs exercem na interação entre candidatos. Neste trabalho, procuramos preencher essa lacuna e desenvolver os resultados previamente obtidos, investigando as funções figurativas que exercem os CMs identificados no mesmo corpus: os

\footnotetext{
${ }^{9}$ Proposto por Roulet (1980), o termo "funções figurativas" diz respeito às funções de determinado recurso verbal no processo de figuração.
} 
debates protagonizados por Fernando Haddad e José Serra, em 2012, e por Dilma Rousseff e Aécio Neves, em 2014.

Para isso, definiremos inicialmente algumas propriedades do processo de figuração de debates eleitorais. Em seguida, investigaremos as funções que os CMs podem exercer no processo de figuração desenvolvido nos dois debates eleitorais componentes do corpus. O estudo das funções figurativas será realizado em dois momentos. Inicialmente, faremos uma caracterização geral dos CMs em termos de seu potencial para o ataque e para a defesa das faces em jogo. Em seguida, articularemos essa caracterização com os três tipos de CMs (autofônico, diafônico e polifônico), para extrairmos as funções que cada tipo exerce.

\section{O Processo de Figuração em Debates Eleitorais}

O debate eleitoral é um gênero de interação fortemente agonal, cujos interactantes centrais (os candidatos) buscam se apresentar como representantes de parcelas da população que, se não são necessariamente antagônicas, não compartilham o mesmo conjunto de valores e opiniões. Por isso, no debate, a discussão e o confronto de ideias e propostas não têm como finalidade o alcance de consenso ou acordo (KERBRAT-ORECCHIONI, 2017). É essa propriedade do debate que faz Doury e Kerbrat-Orecchioni (2011, p. 65) observarem que esse gênero "se caracteriza por um tipo de inversão da norma usual, o acordo sendo 'marcado' em relação ao desacordo”. Essa propriedade do debate tem um impacto sobre a forma como os candidatos, na busca pela adesão do eleitorado, desenvolvem o processo de figuração.

A manutenção do desacordo leva os candidatos a assumirem uma linha de conduta confrontacional. Nos termos das teorias da polidez (BROWN; LEVINSON, 1987; KERBRATORECCHIONI, 1992; LEECH, 1983, 2014), uma linha de conduta confrontacional implica a realização por um candidato de atos ameaçadores tanto para a face positiva do adversário (crítica, acusação), quanto para sua face negativa (pedidos de esclarecimentos, perguntas constrangedoras $)^{10}$. Esse modo de agir dos candidatos leva a crer que o debate se definiria pelo ataque direto e violento à face do adversário, bem como pela intrusão sistemática em seu território,

\footnotetext{
${ }^{10}$ Face positiva e face negativa são os conceitos com os quais Brown e Levinson (1987) reinterpretam, respectivamente, os conceitos de face e território de Goffman (1967[1955], 1973). Em Goffman, a noção de face corresponde "[a]o valor social positivo que uma pessoa efetivamente reivindica para si mesma" (GOFFMAN, 1967[1955], p. 05), ao passo que a noção de território diz respeito à reserva de informações sobre si que o indivíduo tenta preservar. Em Brown e Levinson (1987, p. 61), a face positiva corresponde à “autoimagem consistente e positiva ou 'personalidade' (crucialmente incluindo o desejo de que essa autoimagem seja apreciada e aprovada) reivindicada pelos interactantes", enquanto a face negativa diz respeito à "reivindicação básica de territórios, de preservação pessoal, de direitos a não-distração — i.e. de liberdade de ação e liberdade de imposição".
} 
o que se manifestaria na ausência total de estratégias de polidez (BROWN; LEVINSON, 1987) e na utilização constante de estratégias de impolidez (CULPEPER, 1996, 2005, 2011).

Porém, o que as pesquisas sobre o debate eleitoral revelam é que não se sustenta a hipótese de que o comportamento de um candidato em debate se define pela falta de preocupação com as faces positiva e negativa do adversário (AQUINO, 2008; BLAS-ARROYO, 2003; DOURY; KERBRAT-ORECCHIONI, 2011; FRACCHIOLLA, 2011; KERBRAT-ORECCHIONI, 2016, 2017), não podendo o debate ser identificado com outros gêneros de trocas agonais, como brigas de rua, alguns tipos de operações policiais ou métodos de treinamento praticados nas forças armadas (CULPEPER, 1996, 2011). Essa especificidade do debate eleitoral se explica pela participação de um terceiro: o eleitor/espectador.

O debate não se define como um diálogo, mas como um trílogo (KERBRATORECCHIONI, 1995), já que nele o eleitor assume o papel de um terceiro cuja função é avaliar não só a pertinência das propostas e dos programas de governo de cada candidato, mas ainda o modo como cada um age (sua linha de conduta) em relação ao oponente e ao grupo que este representa. Nesse sentido, o eleitor enquanto terceiro constitui não um ouvinte ou espectador intruso na interação, como o são, por exemplo, os espectadores de uma briga de rua, mas antes a instância a quem os candidatos, direta ou indiretamente, se endereçam, na busca por conquistar sua adesão. $\mathrm{O}$ eleitor é, assim, a razão de ser de todo debate eleitoral (CUNHA; BRAGA, 2016).

Tendo em vista o papel do eleitor no debate, a ausência total de estratégias de polidez (como atos de fala indiretos, modalizadores e hedges, insinuações, honoríficos, voz passiva com apagamento do agente etc. (BROWN; LEVINSON, 1987)) poderia ter como efeito fazer parecer para o eleitor (e não só para o adversário) que aquele que as evita reivindica a face de candidato excessivamente inflexível, pouco condescendente, pouco amigável, frio, distante, indiferente etc. Da mesma forma, a utilização sistemática de estratégias de impolidez (como xingamentos, ofensas, ameaças, atitudes de menosprezo, sarcasmo, tentativas de ridicularizar o outro etc. (CULPEPER, 1996, 2005, 2011)) poderia ter como efeito fazer parecer para o eleitor (e não só para o adversário) que aquele que as utiliza reivindica a face de candidato grosseiro, violento, destemperado, arrogante, estúpido etc.

Desse modo, tanto a ausência total de estratégias de polidez, quanto o uso massivo de estratégias de impolidez seriam prejudiciais para um candidato, porque poderiam fazer os eleitores considerarem que ele não reuniria condições consideradas necessárias para o exercício de uma 
função pública, tais como sensatez, cordialidade, temperança, capacidade de diálogo etc ${ }^{11}$. Assim, em função do eleitor, cujo voto buscam conquistar, os candidatos, em debate eleitoral, costumam empregar estratégias de polidez e não fazer uso sistemático de estratégias de impolidez (DOURY; KERBRAT-ORECCHIONI, 2011, KERBRAT-ORECCHIONI, 2016, 2017).

Contudo, deve-se fazer a ressalva de que, ainda que no debate as estratégias de polidez sejam utilizadas, elas sempre o são de forma moderada. Do mesmo modo, ainda que as estratégias de impolidez não sejam massivamente utilizadas, elas sempre estão presentes. Desse modo, o uso tanto de umas estratégias quanto de outras costuma ser parcimonioso, porque, nesse gênero, tanto o excesso de estratégias de polidez quanto a ausência total de estratégia de impolidez poderiam contribuir para criar o efeito de que a interação entre os candidatos se desenvolve de forma excessivamente amigável e harmoniosa, da qual o desacordo, que, como vimos, é a norma do debate, estaria ausente ou implícito (KERBRAT-ORECCHIONI, 2017).

Dessa forma, parte importante da linha de conduta seguida pelos candidatos é o uso de uma linguagem que permita a cada um manter claros os pontos que o opõem ao adversário, evidenciando, no entanto, que essa oposição se dá no âmbito de projetos, ideias e valores morais e éticos. Por isso, o desacordo que caracteriza todo debate eleitoral implica um processo de figuração tenso, cujo desenvolvimento, em função do eleitor/espectador, obriga os candidatos a estarem constantemente atentos ao modo como, por meio da linguagem, constroem conjuntamente faces e territórios.

Como exposto na Introdução, o campo das teorias da im/polidez tradicionalmente se centra no papel de elementos microlinguísticos (lexicais e gramaticais), investigando como construções sintáticas, tempos verbais, advérbios e pronomes podem funcionar como estratégias de polidez ou de impolidez. Tendo em vista que outros planos da organização do discurso (como as relações de discurso) podem desempenhar papel importante no modo como os interactantes negociam imagens identitárias (CUNHA, 2014, 2015, 2017a, 2017b, 2019, CUNHA; MARINHO, 2017), investigaremos a seguir as funções figurativas de uma relação de discurso, o comentário metadiscursivo, no gênero debate eleitoral.

\footnotetext{
${ }^{11}$ Nos últimos anos e em diferentes partes do mundo, os casos de candidatos que, para alcançarem o poder por vias consideradas democráticas, têm se valido em suas campanhas eleitorais do chamado "discurso de ódio", discurso em que escasseiam estratégias de polidez e proliferam as de impolidez perpetradas contra oponentes e minorias sociais, constituem contra-exemplos a essa tendência mais geral identificada pelos estudiosos de debates eleitorais. O estudo aprofundado desses casos, cujo exemplo emblemático é o atual presidente dos Estados Unidos, Donald Trump, pode contribuir para saber em que medida uma nova linguagem política estaria emergindo ou em que medida essa linguagem manter-se-ia como um fenômeno marginal e passageiro.
} 


\section{As FunÇões Figurativas do Comentário Metadiscursivo}

Para entendermos as funções figurativas dos CMs presentes em nosso corpus, realizamos seu estudo em duas etapas. Na primeira, investigamos se todas as ocorrências de CMs em nosso corpus atuam no processo de figuração, constituindo recursos com que os candidatos atacam ou defendem as faces em jogo. Em seguida, realizamos uma análise mais minuciosa das funções de cada tipo de CM identificado em Cunha e Braga (2018): autofônico, diafônico e polifônico. Para isso, correlacionamos os resultados da primeira etapa do estudo, com as instâncias enunciativas a que cada tipo corresponde: o próprio candidato, o interlocutor imediato e terceiros, respectivamente.

\subsection{Primeira etapa da análise}

Para realizar a primeira etapa da análise das funções figurativas dos CMs, tomamos as propriedades ataque e defesa como traços a serem atribuídos a cada comentário do corpus, tendo em vista o fato de serem essas as funções básicas que um recurso verbal pode exercer no processo de figuração. É o que atestam as teorias da polidez, centradas basicamente nos recursos de defesa (proteção, valorização, reparação) das faces em jogo, bem como as teorias da impolidez, voltadas basicamente para o estudo dos recursos de ataque (ofensa, agressão, destruição) dessas faces (CULPEPER; TERKOURAFI, 2017). Nessa perspectiva, um CM pode ser produzido com o fim de atacar a face do adversário, enquanto outro pode ser produzido com o fim de defender a face do locutor que os produz ou a de terceiros.

Além disso, cada uma dessas propriedades pode se manifestar no discurso de forma escalar ou gradual, já que dois CMs podem ser produzidos com o fim de atacar a face do adversário, mas um pode ter um grau de agressividade mais acentuado do que o outro, o que representamos com os símbolos $+\mathrm{e}-$. Assim, esses símbolos $+\mathrm{e}-$ devem ser entendidos como representando não a total presença ou ausência das propriedades ataque e defesa (em termos de sim ou não), mas a proximidade do CM de uma das extremidades dos polos das escalas (contínuos) de ataque e defesa (em termos de maior ou menor intensidade $)^{12}$.

Combinados, os traços ataque e defesa e os símbolos $+\mathrm{e}-$ deram origem a quatro possibilidades teóricas para o estudo das funções figurativas dos CMs. A combinação desses traços e as possibilidades teóricas que dela surgiram podem ser visualizadas no esquema da figura 1, que

\footnotetext{
${ }^{12}$ Com objetivos distintos dos nossos, Leech $(1983,2014)$ também evidenciou a natureza escalar da polidez. Para o autor, os recursos linguísticos usados na construção dos enunciados permitem ordená-los numa escala de polidez, a escala pragmalinguística. Porém, um enunciado considerado polido na escala pragmalinguística pode, dependendo da situação, ser impolido ou menos polido. Nesse sentido, o contexto permite ordenar os enunciados segundo outra escala de polidez, a escala sócio-pragmática.
} 
teve como finalidade oferecer instrumentos de análise para, durante o estudo qualitativo de cada CM, situá-lo em uma escala de graus maiores ou menores de ataque e de defesa de faces (positivas e/ou negativas $)^{13}$.

Figura 1 - Esquema de ataque/defesa

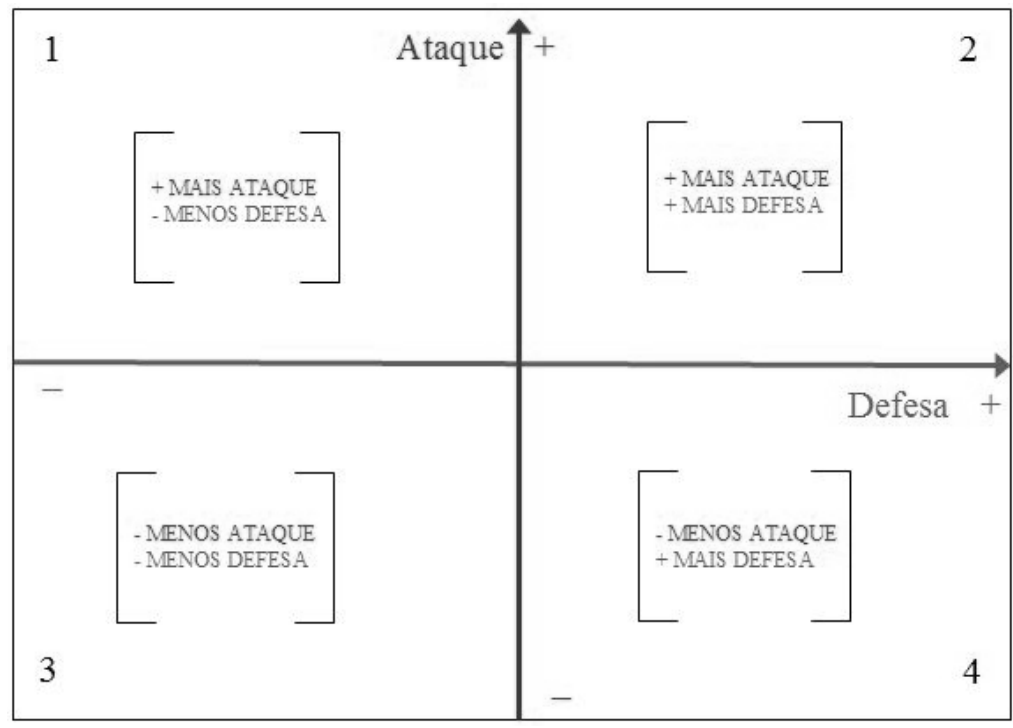

Fonte: Elaboração dos autores.

A aplicação desse esquema ao estudo dos debates do corpus revelou que todas as 121 ocorrências de CM identificadas foram utilizadas pelos candidatos para realizar diferentes graus de ataque e defesa das faces positiva e/ou negativa de determinada instância (o próprio locutor, o interlocutor ou um terceiro). A seguir, explicitaremos como os parâmetros de cada quadrante do esquema foram utilizados na análise do corpus.

O primeiro quadrante do esquema reúne os traços +ataque e -defesa. Isso significa que um CM caracterizado por esses traços auxiliará seu produtor a se apresentar como um candidato mais interessado em atacar as faces positiva e/ou negativa de uma instância enunciativa do que em proteger essas faces ou as de outra instância. Mesmo que, no gênero debate, todo ataque ao adversário possa ser interpretado como um autoelogio indireto ou implícito (KERBRATORECCHIONI, 2017), há CMs em que um candidato apenas ataca e não faz nenhum defesa explícita de si ou de outros. É o que exemplifica o excerto (01), em que Haddad produz um CM que ataca a face de Serra e que não apresenta marcas linguísticas que evidenciem cuidado com a face de qualquer instância enunciativa (o próprio Haddad, o adversário ou um terceiro) ${ }^{14}$.

\footnotetext{
${ }^{13} \mathrm{O}$ esquema que propomos deve ser entendido como um conjunto de ferramentas heurísticas adequadas para uma aproximação do fenômeno em estudo, quando da análise qualitativa de cada CM presente em nosso corpus. Nesse sentido, não reivindicamos para os traços e as escalas de que se compõe uma validade geral ou uma aplicabilidade irrestrita a outros contextos.

${ }^{14}$ Em todos os excertos deste trabalho, os CMs estão marcados em itálico.
} 
José Serra: O que eu devo dizer pela segurança é o seguinte, como prefeito eu vou da batalha, vou ser um prefeito ativista para ajudar o Governo do Estado na tarefa da segurança. (...)

Fernando Haddad: Bom, o candidato não respondeu a que atribui a escalada da violência no último ano. (...)

Já o segundo quadrante do esquema reúne os traços +ataque e +defesa, e, por isso, o CM que nele puder ser classificado permitirá ao locutor realizar duas ações concomitantes: atacar a face de uma instância enunciativa e defender a face de outra. De modo geral, os CMs do corpus que podem ser assim interpretados foram usados por um locutor para atacar a face positiva ou negativa do adversário e proteger a própria face positiva, como evidenciam os excertos (02) e (03), retirados um de cada debate do corpus.

02) Fernando Haddad: A tua propaganda eleitoral não reflete a vida da cidade. Você não está sabendo o que está acontecendo, tem criança brincando com esgoto a céu aberto, tem mães que não têm onde deixar seus filhos. Questão da habitação é questão séria porque inclusive envolve o meio-ambiente. Talvez se você corresse mais a cidade sua indignação fosse tão grande quanto a minha no dia de hoje.

03) Aécio Neves: (...) A senhora será a primeira presidente da República pós-plano real que deixará o país com uma inflação maior do que aquela que recebeu.

Dilma Rousseff: Eu acho que o senhor está mal informado, porque quem deixou o país com uma inflação maior do que recebeu foi o governo tucano do Fernando Henrique. (...)

Em (02), Haddad produz o CM para apresentar o adversário como um candidato que desconhece os problemas da própria cidade que pretende governar, atacando sua face, e, ao mesmo tempo, se apresentar como um candidato em quem esses mesmos problemas causam indignação, defendendo/valorizando sua própria face. Já em (03), Dilma se defende do ataque previamente perpetrado pelo adversário e o ataca, ao acusá-lo de estar mal informado. Logo em seguida, na justificativa iniciada pelo conector porque, ela ataca novamente o adversário, ao criticar a atuação de um de seus colegas de partido (o ex-presidente Fernando Henrique Cardoso).

Porém, a natureza escalar das propriedades ataque e defesa permite chamar a atenção para o fato de que os CMs não possuem o mesmo grau de intensidade de ataque ou defesa para as faces em jogo em cada debate. Nos excertos, o primeiro CM, produzido por Haddad, pode ser interpretado como mais agressivo para a face do adversário do que o segundo, produzido por Dilma. Isso porque o primeiro representa o adversário como um político distante de grande parte do eleitorado, o eleitor mais carente, morador das regiões mais pobres e periféricas da cidade, enquanto o segundo traz uma crítica à política econômica conduzida por um colega de partido de Aécio, ainda que a campanha desse candidato se apoiasse intensamente nos supostos méritos dessa política.

O terceiro quadrante possui traços -ataque e -defesa, e, por isso, o CM caracterizado por esses traços é mais neutro. A natureza confrontacional do gênero debate faz com que CMs com esses traços sejam raros no nosso corpus. Contudo, o excerto (04) constitui um exemplo, uma vez 
que, com o comentário, o candidato não ataca nem defende de modo direto e explícito a face de uma instância enunciativa.

04) Elisabete Maria: (...) Qual a sua proposta para que pessoas maduras tenham sua experiência de trabalho valorizada e possam manter sua empregabilidade.

Aécio Neves: Elisabete, você toca numa questão essencial em relação ao Brasil que nós queremos construir, o Brasil do futuro. (...)

No entanto, cabe ressaltar que mesmo esse comentário exerce uma função figurativa no debate, já que, ainda que implicitamente, é possível dele inferir um elogio à pergunta da integrante da plateia e, portanto, uma valorização de sua face, bem como um autoelogio indireto, na medida em que o candidato se apresenta como um político que sabe o que é necessário para construir "o Brasil do futuro". Assim, do ponto de vista da escala da defesa (fig. 1), esse comentário exerce função figurativa, mas em grau mínimo, por apresentar uma (auto)defesa indireta e implícita e, desse modo, estar mais próximo do polo negativo da escala do que um comentário, aliás frequente no debate entre Dilma e Aécio, em que o candidato dissesse: "Muito boa a sua pergunta".

Por fim, o quarto quadrante reúne os traços -ataque e +defesa. Os CMs que se caracterizam por esses traços são aqueles com os quais os candidatos assumem uma postura mais defensiva, caso a instância cuja face se defende seja o próprio candidato, como ocorre no excerto (05), ou uma postura mais amigável, caso a instância cuja face se defende seja o eleitor, como ocorre no excerto (06).

05) José Serra: Olha, hoje quando se fala em corrupção, a lembrança imediata é o mensalão. Na verdade, a cúpula do PT foi considerada culpada de desvio de dinheiro público. Para compra de votos. Mais do que isso, foi julgada e condenada. Condenada a prisão. Eu queria que você explicasse, Fernando Haddad, aos paulistanos, por que isso aconteceu. Como é mesmo, de que maneira isso ocorreu em Brasília com o PT?

Fernando Haddad: (...) Eu sou uma pessoa que tem doze anos de vida pública, uma reputação que ninguém discute, nem você em 60 dias de campanha foi capaz de me atacar na honra porque você sabe da minha conduta (...).

06) Luiz Alexandre Filho: (...) Qual será a sua política para quem mora de aluguel, pois está cada vez mais difícil e muito mais caro alugar uma casa, os preços estão muito acima da inflação? (...)

Dilma Rousseff: Luiz Alexandre, muito boa a pergunta. (...)

Esses dois exemplos, ainda que possam ser classificados com os mesmos traços (-ataque e +defesa), apresentam, no entanto, graus distintos de agressividade e, portanto, se situam em pontos diferentes da escala do ataque (fig. 1). Como ocorre no CM produzido por Haddad, aquele que se defende de ataque recebido acaba, em alguma medida, agredindo a face do autor do ataque. Já aquele que defende o outro, como ocorre no CM produzido por Dilma, o valoriza e não causa danos em sua face. Esse fenômeno parece se explicar pelo fato de que toda defesa corresponde, de forma mais ou menos clara, a um elogio, já que defender uma instância enunciativa é realçar qualidades e méritos que, sem a defesa, talvez não fossem notados. Como em debates autoelogiar-se é 
implicitamente depreciar o adversário (FRACCHIOLLA, 2011, KERBRAT-ORECCHIONI, 2017), entende-se por que o CM produzido por Haddad, no excerto (05), é mais agressivo do que o produzido por Dilma, no excerto (06).

\subsection{Segunda etapa da análise}

Com base no esquema descrito anteriormente (fig. 1), realizamos a segunda etapa da análise das funções figurativas dos CMs presentes no corpus, correlacionando o esquema com os três tipos de comentários metadiscursivos identificados em Cunha e Braga (2018): autofônico, diafônico e polifônico. Com a análise, que será apresentada na sequência, procuramos investigar, assim, as funções figurativas de cada tipo de CM, verificando o papel de cada CM do corpus na construção conjunta das faces positivas e negativas dos candidatos. Como veremos, os resultados revelaram que os tipos de CMs distribuem-se desigualmente pelos quadrantes do esquema, o que significa que cada tipo é especializado mais no ataque ou na defesa das faces em jogo. Por motivo de espaço, nos subitens a seguir, apresentaremos apenas alguns CMs para ilustrar os resultados a que chegamos.

\subsubsection{Comentário metadiscurso autofônico}

Como informado na Introdução, esse tipo de CM permite ao locutor avaliar negativa ou positivamente seu próprio comportamento linguageiro ao longo do debate ou mesmo ao longo da campanha eleitoral (CUNHA; BRAGA, 2018). Os CMs autofônicos identificados no corpus reúnem os traços -ataque e +defesa (quadrante 4) ou os traços +ataque e +defesa (quadrante 2). Assim, com esse tipo de CMs, o candidato sempre defende (valoriza) e nunca deprecia (ataca) sua própria face, o que faz com que esses CMs sejam sempre autoelogios mais ou menos claros. É o que exemplificam os CMs presentes nos excertos (07) e (08).

07) Aécio Neves: Eu governei Minas, com um orgulho enorme, candidata, por oito anos, e levei Minas Gerais, que não é o mais rico dos estados brasileiros, é o segundo mais populoso, a ter a melhor educação fundamental do Brasil. E quem fez, candidata, tem mais autoridade para dizer que vai fazer.

08) Fernando Haddad: Serra, com o perdão da palavra, a educação não é propriamente a tua área. Professor não é reciclado nem treinado. Essas palavras não se adequam ao educador. O educador é formado, tem sua formação inicial, continuada. Reciclagem e treinamento você usa para outras coisas, você não pode usar para professor. Estou te orientando para você não cometer esse deslize novamente.

Os CMs autofônicos permitem ao locutor retomar o que disse ou a linha de conduta previamente assumida, para mostrar (ao eleitor) que possui determinadas qualidades: autoridade (excerto 07), sabedoria (excerto 08). Por essa razão, ambos os CMs podem ser marcados com o traço +defesa. Porém, em alguns CMs autofônicos identificados no corpus, há ainda um ataque 
direto e evidente à face do adversário, como no excerto (08) produzido por Haddad, enquanto em outros esse ataque não é direto e pode ser até negado, como no excerto (07) produzido por Aécio. Por isso, (07) é marcado com o traço -ataque, ao passo que (08), com o traço +ataque.

\subsubsection{Comentário metadiscursivo diafônico}

Esse tipo de CM é aquele com o qual o locutor avalia negativa ou positivamente o comportamento linguageiro do interlocutor (adversário ou integrante da plateia) (CUNHA; BRAGA, 2018). Como revelado em Cunha e Braga (2018), esse foi o tipo de CM que apresentou maior número de ocorrências. No total de $121 \mathrm{CMs}$ identificados, 89 pertencem a esse tipo. Por isso, esses CMs são aqueles que, no corpus estudado, desempenham uma maior gama de funções e, consequentemente, apresentam uma maior complexidade. Para evidenciar as funções desses CMs no corpus, vamos estudá-los seguindo os quadrantes do esquema proposto na figura 1.

No primeiro quadrante do esquema, encontram-se os CMs que reúnem os traços de +ataque e -defesa. Por essa razão, esses são os CMs mais agressivos para as faces positiva e/ou negativa do adversário, como evidencia o excerto (09).

09) Fernando Haddad: (...) Eu não vejo em nenhum momento da sua propaganda eleitoral de rádio e TV você mencionar a necessidade de parceria com o Governo Federal. É uma atitude política, é um esquecimento? O que vem a ser? Isso o prefeito de São Paulo desconsiderar esta possibilidade?

José Serra: Hoje a prefeitura tem 83 convênios em parcerias com o governo federal. Esta história que não se faz coisa com o governo federal é mentira.

Como revela esse exemplo, um candidato costuma produzir CMs diafônicos de +ataque e defesa para refutar acusação feita previamente pelo adversário, acusando-o de ser mentiroso. Dessa forma, ainda que, de modo geral, esses CMs sejam bastante agressivos, eles aparecem (para o eleitor) não como uma manifestação gratuita de agressividade, o que poderia ser prejudicial para a face positiva de seu produtor, mas como uma autodefesa motivada por ataque previamente recebido. Muitos desses CMs costumam assumir uma formulação curta, reduzida à acusação de que o adversário mentiu ou de que sua fala não merece crédito, como nesses exemplos extraídos dos dois debates:

10) Aécio Neves: Mais um engano da senhora (...).

11) Aécio Neves: Não é verdade (...).

12) Dilma Rousseff: Eu não acredito nisso, candidato. Eu não acredito nisso (...).

13) Dilma Rousseff: (...) Me desculpe, candidato, eu não acredito (...).

14) Dilma Rousseff: Eu acho que o senhor está mal informado (...)

15) Fernando Haddad: Serra, os dados estão completamente equivocados a esse respeito (...). 
A listagem desses CMs diafônicos de +ataque e -defesa revela uma propriedade importante dos debates, propriedade já apontada no item anterior. Ainda que o ataque seja uma constante no debate, tendo em vista a natureza confrontacional do gênero, não é frequente o uso de estratégias de impolidez, intensificando o grau de agressividade de um ato ameaçador para as faces do adversário. Ao contrário, os CMs diafônicos contendo ataques (críticas) costumam ser formulados com estratégias de polidez que mitigam os danos que podem provocar à imagem pública do adversário. Assim, são raras as ocorrências de palavras como mentira ou mentiroso, como no excerto (09). De modo geral, como nos excertos (10-15), utilizam-se estratégias de polidez, como lítotes (dizer Não é verdade é menos agressivo do que dizer É mentira), a atribuição de problemas a outras instâncias e não a quem os proferiu ("os dados estão completamente equivocados"), modalizadores (“eu acho"), expressões formulaicas de polidez (“Me desculpe"). Com o uso dessas estratégias, embora o locutor, por meio do CM diafônico de +ataque e -defesa, tenha como finalidade principal o ataque do adversário, a consideração do eleitorado o obriga a se valer de estratégias de polidez, para que sua própria face não seja prejudicada.

O segundo quadrante apresenta os traços +ataque e +defesa. No corpus, os CMs diafônicos que reúnem esses traços costumam ser utilizados pelo candidato para atacar a face do adversário e proteger sua própria face, como em excerto já apresentado e reproduzido em (16).

16) Fernando Haddad: A tua propaganda eleitoral não reflete a vida da cidade. Você não está sabendo o que está acontecendo, tem criança brincando com esgoto a céu aberto, tem mães que não têm onde deixar seus filhos. Questão da habitação é questão séria porque inclusive envolve o meio-ambiente. Talvez se você corresse mais a cidade sua indignação fosse tão grande quanto a minha no dia de hoje.

Mas esses CMs podem ser produzidos ainda com o fim duplo de atacar a face do adversário e proteger a face de terceiros, como nos excertos (17) e (18).

17) José Serra: Olha, como eu disse, o piso salarial foi elevado de 1200, para 2600. Isso valoriza o professor, nós vamos além disso, dar $25 \%$ de reajuste acumulado nos próximos dois anos. (...) Mais ainda, nós vamos criar um centro de treinamento e reciclagem permanente dos professores do município (...).

Fernando Haddad: Serra, com o perdão da palavra, a educação não é propriamente a tua área. Professor não é reciclado nem treinado. Essas palavras não se adequam ao educador. O educador é formado, tem sua formação inicial, continuada. Reciclagem e treinamento você usa para outras coisas, você não pode usar para professor (...).

18) Dilma Rousseff: O senhor concorda com o que fala o seu candidato a Ministro da Fazenda, que diz que o salário mínimo está alto demais?

Aécio Neves: Candidata, não é justo colocar palavras na boca de alguém que não está aqui para respondê-la. (...)

Em ambos os CMs, os candidatos que os elaboram atacam seus adversários, acusando-os de incompetência e despreparo (17) ou de leviandade e injustiça (18). Ao mesmo tempo, com esses CMs, os candidatos defendem as faces de terceiros: professores (17) e membro da equipe do candidato (18). 
Em relação ao terceiro quadrante, os CMs diafônicos que reúnem os traços -ataque e defesa parecem ser raros em debates eleitorais, dada sua maior neutralidade. No nosso corpus, identificamos apenas uma ocorrência, já apresentada anteriormente e reproduzida em (19). Ela foi produzida por Aécio Neves em resposta à pergunta de uma integrante da plateia.

Elisabete Maria: (...) Qual a sua proposta para que pessoas maduras tenham sua experiência de trabalho valorizada e possam manter sua empregabilidade.

Aécio Neves: Elisabete, você toca numa questão essencial em relação ao Brasil que nós queremos construir, o Brasil do futuro. (...)

Como informado, um CM como esse exerce função figurativa, mesmo que em grau mínimo na escala da defesa (fig. 1). Com ele, o candidato elogia implicitamente a pergunta da integrante da plateia e a representa como alguém que conhece as questões essenciais para o país ("você toca numa questão essencial em relação ao Brasil") e que pertence a um "nós" que deseja "construir o Brasil do futuro", o que não deixa de constituir uma valorização de sua face de eleitora ou cidadã e ainda um autoelogio.

Por fim, o quarto quadrante apresenta os traços de -ataque e +defesa. Os CMs diafônicos que se caracterizam por esses traços são de dois tipos. O primeiro são aqueles com os quais o candidato comenta a fala do adversário, para se autoelogiar e/ou revelar que, ao contrário do que disse seu oponente, ele apresenta as qualidades necessárias ao exercício do cargo em disputa. Nesse caso, o CM diafônico costuma ser produzido após um ataque do adversário e constitui um recurso de autodefesa, como nos excertos (20) e (21), produzidos pelo mesmo candidato, José Serra.

20) Fernando Haddad: Na minha opinião, o candidato José Serra tem uma visão muito restrita da mulher. Ele vê a mulher apenas como gestante. (...)

José Serra: Olha, eu não vejo a mulher só como gestante não, eu vejo a mulher como filha, eu vejo a mulher como esposa, vejo a mulher como mãe, vejo a mulher como cidadã. E de maneira integral, além do mais isso é meio óbvio (...).

21) Fernando Haddad: Serra, eu queria voltar à questão dos corredores. Você procura tangenciar essa questão, afinal de contas você é a favor ou contra? Se é a favor, por que vocês não construíram nenhum quilômetro nos últimos quatro anos embora tenham prometido 66 quilômetros? (...)

José Serra: Olha, primeiro essa história de não ter feito corredor, nós fizemos, por exemplo o corredor Tiradentes, expresso Tiradentes e o corredor Diadema, São Mateus, Diadema, que é feito pelo estado. (...)

O segundo tipo de CMs diafônicos de -ataque e +defesa são aqueles com os quais um candidato defende (elogia) a fala de integrante da plateia convidado a fazer perguntas, produzindo comentários como "Muito boa sua pergunta". Houve ocorrências desses CMs apenas no debate entre Dilma e Aécio, dada a possibilidade de nesse debate integrantes da plateia fazerem perguntas. 


\subsubsection{Comentário metadiscursivo polifônico}

Esse subtipo de comentário metadiscursivo é aquele utilizado para avaliar negativa ou positivamente o comportamento linguageiro de terceiros (correligionários, assessores, o programa político etc) (CUNHA; BRAGA, 2018). Os CMs polifônicos do nosso corpus podem ser caracterizados pelos traços +ataque e -defesa (quadrante 1) ou pelos traços +ataque e +defesa (quadrante 2). Isso significa que o candidato que produz um $\mathrm{CM}$ polifônico tem sempre como finalidade atacar um terceiro, mas esse ataque pode ou não ser acompanhado da defesa de uma instância enunciativa, instância que, nas ocorrências identificadas no corpus, é sempre o próprio candidato. O excerto (22) traz um exemplo de CM polifônico de +ataque e -defesa produzido por Aécio Neves.

22) Renata Elizondo Souza: O que o candidato pretende fazer (9) para que esse futuro seja possível para os nossos filhos e que o Brasil do presente valorize e respeite a educação?

Dilma Rousseff: (...) Nós vamos fazer 6 mil creches. (6) Duas mil já entregamos, estamos construindo mais 4 mil. Se eu for eleita, vou construir mais tantas creches quanto forem o necessário, primeiro para a gente universalizar de quatro a cinco anos a pré-escola e ampliar o número de crianças de zero a três. Agora, eu queria te dizer uma coisa, nós aprovamos uma lei no Congresso que dá $75 \%$ dos royalties e $50 \%$ do fundo social do pré-sal para educação. Para que? Para pagar melhor os professores. Essa é a condição para esse país ter educação de qualidade.

Aécio Neves: Renata, eu volto a sua pergunta, né. A gente escuta sempre as mesmas promessas, os mesmos compromissos, lamentavelmente, estão no poder há doze anos e não fizeram aquilo que dizem que vão fazer. (...)

Nesse excerto, com o CM, o candidato comenta a resposta dada pela adversária à pergunta feita por uma integrante da plateia. Esse CM é polifônico e não diafônico, porque, ao produzir sua réplica, o candidato elege a integrante da plateia como interlocutora imediata e transforma a adversária em um terceiro. No CM, o candidato ataca a face da adversária, ao desacreditar suas promessas, e não defende ou protege de forma explícita a face de nenhuma outra instância enunciativa.

A seguir, os excertos (23) e (24) trazem exemplos de CMs polifônicos que reúnem os traços +ataque e +defesa. Como exposto, um candidato costuma produzir esses CMs para atacar a face do adversário e proteger sua própria face.

23) Fernando Haddad: (...) Nós queremos investir no metrô, inclusive eu pretendo trazer recurso federal para o metrô que quase nunca foi pedido, quando foi atendido. Para fazer o quê? Um cronograma de obras. A companhia tem que apresentar um cronograma e se eu estou colocando dinheiro novo, isso tem que representar cronograma novo, novas estações e novas linhas antecipadas, e não adiando como aconteceu com a linha seis que vocês já adiaram para 2019 e a Brasilândia sabe disso.

José Serra: (...) Olha, nessa questão do metrô, também fala-se muito quando se critica, mas propõe-se pouco.

24) Aécio Neves: (...) A revista Veja hoje publica que o delator, um dos delatores do "petrolão", disse que a senhora e o ex-presidente Lula tinham conhecimento da corrupção na Petrobras, uma oportunidade da senhora responder aos brasileiros. A senhora sabia, candidata, da corrupção na Petrobras? 
Dilma Rousseff: Candidato, é fato que o senhor tem feito uma campanha extremamente agressiva a mim. Isso é reconhecido por todos os eleitores. Agora essa revista que fez e que faz sistematicamente oposição a mim, faz uma calúnia e uma difamação do porte que ela fez hoje. E o senhor endossa. Candidato, a revista Veja não apresenta nenhuma prova do que faz. (...)

Em (23), Serra busca se defender da crítica previamente feita por Haddad, segundo o qual o adversário é incapaz de propor melhorias para as situações problemáticas relacionadas ao metrô de São Paulo. No CM, Serra ataca a face de Haddad, ao tentar desacreditar sua proposta de elaborar um cronograma de obras. No entanto, o ataque se faz na terceira pessoa, já que o candidato não identifica o alvo da crítica ("fala-se muito", “propõe-se pouco"). Adotando esse procedimento, o candidato ameniza o grau de agressividade do ataque ao adversário. Afinal, dizer "você fala muito, mas propõe pouco" poderia soar (ao eleitor) como uma crítica mais agressiva.

Já no excerto (24), Dilma Rousseff produz dois CMs polifônicos (trechos em itálico) com o fim de atacar uma instância (a revista Veja) que não corresponde ao adversário. Ao utilizar esses CMs, a candidata ataca a face da revista com a finalidade de se defender de acusação feita pela própria revista e utilizada pelo adversário na formulação de sua pergunta. O que faz desse excerto um recurso particularmente importante de autodefesa é a estratégia de intercalar um CM diafônico ("E o senhor endossa") entre os CMs polifônicos. Ao agir dessa forma, a candidata não só refuta as acusações da revista, qualificando-as de calúnias, como sustenta que o adversário endossa essas calúnias, com fins eleitoreiros. Desse modo, essa combinação de diferentes tipos de CMs permite à candidata atribuir ao adversário os defeitos de que este a acusou previamente: falta de lisura, idoneidade, ética ou honestidade.

\section{CONSIDERAÇÕES FINAIS}

Tendo como ponto de partida pesquisa previamente realizada sobre a noção de comentário metadiscursivo (CUNHA; BRAGA, 2018), o presente estudo teve o intuito de revelar as funções figurativas que essa relação de discurso pode exercer em debates eleitorais. Para isso, desenvolvemos, inicialmente, um esquema (fig. 1) formado por duas escalas (ataque e defesa) que vão do menor ao maior grau de intensidade, partindo da hipótese de que todo CM pode ser utilizado para atacar e/ou defender, de forma mais ou menos intensa, as faces positivas e/ou negativas em jogo numa interação.

Em seguida, correlacionamos esse esquema com os tipos de CM: autofônico, diafônico e polifônico. A partir dessas análises, pudemos chegar aos seguintes resultados sobre as funções figurativas de cada tipo de $\mathrm{CM}$ em debates eleitorais: 
- CM autofônico reúne ou os traços -ataque e +defesa (quadrante 4, fig. 1) ou os traços +ataque e +defesa (quadrante 2). Em ambos os casos, o candidato sempre o utiliza para defender (valorizar) sua própria face (+defesa). Desses CMs, os que são marcados com o traço +ataque possibilitam ainda um ataque direto à face do adversário, enquanto os que são marcados com o traço -ataque não realizam ataque explícito às faces de nenhuma instância enunciativa.

- CM diafônico desempenha uma maior gama de funções e, consequentemente, apresenta uma maior complexidade. Os CMs de +ataque e -defesa (quadrante 1) são os mais agressivos para as faces positiva e/ou negativa do adversário e permitem ao seu produtor refutar acusação feita previamente. Os CMs de +ataque e +defesa (quadrante 2) costumam ser utilizados pelo candidato para atacar a face do adversário e defender sua própria face ou a face de terceiros. Os CMs de -ataque e -defesa (quadrante 3) parecem ser raros em debates eleitorais, por serem mais neutros, mas, ainda que em grau mínimo, exercem função figurativa, por poderem trazer, por exemplo, um elogio implícito a alguma instância enunciativa. Os CMs de -ataque e +defesa (quadrante 4) costumam ser usados pelo candidato para se autoelogiar ou elogiar integrante da plateia convidado a fazer perguntas.

- CMs polifônicos caracterizam-se pelos traços +ataque e -defesa (quadrante 1) ou pelos traços +ataque e +defesa (quadrante 2). Assim, o intuito de candidato que produz um CM polifônico é atacar um terceiro (+ataque), mas esse ataque pode ou não ser acompanhado da defesa de outra instância enunciativa, instância que costuma ser o próprio candidato.

A relevância desses resultados está em revelar a complexidade do papel que a relação de comentário metadiscursivo exerce no processo de figuração desenvolvido pelos participantes de debates eleitorais. Dadas as funções que exerce, essa relação de discurso auxilia cada candidato a desempenhar uma linha de conduta tensa, por meio da qual, em virtude do eleitorado, dosa constantemente a intensidade dos ataques e das defesas que realiza em relação às suas próprias faces, bem como às faces do adversário e de terceiros. Nesse sentido, esta pesquisa contribui para evidenciar que não apenas itens de natureza microlinguística, como os tradicionalmente abordados pelas teorias da im/polidez (cf. CULPEPER; TERKOURAFI, 2017), mas também as relações de discurso, a exemplo do comentário metadiscursivo, devem ter lugar de destaque no estudo do modo como os interactantes, em diferentes contextos, constroem conjuntamente imagens identitárias. 


\section{REFERÊNCIAS}

AQUINO, Z. G. O. 2008. Diálogos da mídia: o debate televisivo. In: PRETI, D. (org.) Diálogos na fala e na escrita. São Paulo: Humanitas, 2008. p. 171-194.

BLAS-ARROYO, J. L. "Perdóneme que se lo diga, pero vulve usted a faltar a la verdade, señor Gonzáles": form and function of politic verbal behavior in face-to-face Spanish political debates. Discourse \& Society, Nova York, v. 14, n. 4, p. 395-423, 2003.

BROWN, P.; LEVINSON, S. C. Politeness: some universals in language use. Cambridge, Cambridge University Press, 1987.

CULPEPER, J. Towards an anatomy of impoliteness. Journal of Pragmatics, Amsterdã, v. 25, n. 3, p. 349-367, 1996.

CULPEPER, J. Impoliteness and entertainment in the television quiz show: The Weakest Link. Journal of Politeness Research, Berlim, n. 1, p. 35-72, 2005.

CULPEPER, J. Impoliteness: using language to cause offense. Cambridge: Cambridge University Press, 2011.

CULPEPER, J.; TERKOURAFI, M. Pragmatic approaches (im)politeness. In: CULPEPER, J.; HAUGH, M.; KÁDÁR, D. Z. (orgs.), The Palgrave Handbook of Linguistic (Im)politeness. London: Palgrave, 2017. p. 11-38.

CUNHA, G. X. As condições de emergência da função reformulativa do conector quando em reportagens. Revista de Estudos da Linguagem, Belo Horizonte, v. 22, n. 1, p. 143-170, 2014.

CUNHA, G. X. As relações retóricas e a negociação de faces em debate eleitoral. Confluência, Rio de Janeiro, v. 1, p. 205-238, 2015.

CUNHA, G. X. O papel dos conectores na co-construção de imagens identitárias: o uso do mas em debates eleitorais. ALFA, São José do Rio Preto, v. 61, n. 3, p. 599-623, 2017 a.

CUNHA, G. X. Conectores e processo de negociação: uma proposta discursiva para o estudo dos conectores. Fórum Linguístico, Santa Catarina, v. 14, p. 1699-1716, 2017 b.

CUNHA, G. X. Estratégias de impolidez como propriedades definidoras de interações polêmicas. Delta: Documentação e Estudos em Linguística Teórica e Aplicada, São Paulo, v. 35, n. 2, p. 1-28, 2019.

CUNHA, G. X.; BRAGA, P. B. O comentário metadiscursivo como estratégia argumentativa em debates eleitorais. EID\&A, Ilhéus, v. 12, p. 101-118, 2016.

CUNHA, G. X.; BRAGA, P. B. Definindo o comentário metadiscursivo em uma perspectiva interacionista da Análise do Discurso. SCRIPTA, Belo Horizonte, v. 22, p. 171-188, 2018.

CUNHA, G. X.; MARINHO, J. H. C. A expressão conectiva na verdade: contribuições para uma abordagem polifônica dos conectores reformulativos. Signo, Santa Cruz do Sul, v. 42, p. 53-64, 2017.

DOURY, M.; KERBRAT-ORECCHIONI, C. La place de l'accord dans l'argumentation polémique: les cas du débat Sarkozy/Royal (2007). A contrario, Paris, v. 16, n. 2, p. 63-87, 2011.

DUCROT, O. O dizer e o dito. Campinas: Pontes, 1987.

FRACCHIOLLA, B. 2011. Politeness as strategy of attack in a gendered political debate - the Royal-Sarkosy debate. Journal of Pragmatics, Amsterdã, v. 43, p. 2480-2488, 2011. 
GOFFMAN, E. On face-work: an analysis of ritual elements in social interaction. In: GOFFMAN, E. Interaction Ritual: essays on face-to-face behavior. New York: Pantheon Books, 1967[1955]. p. 5-45.

GOFFMAN, E. La mise em scène de la vie quotidienne: les relations em public. Paris : Les Éditions de Minuit, 1973.

KERBRAT-ORECCHIONI, C. Les interactions verbales. Paris: Colin, 1992.

KERBRAT-ORECCHIONI, C. Introduction. In: KERBRAT-ORECCHIONI, C.; PLANTIN, C. (orgs.). Le trilogue. Lyon : Presses Universitaires de Lyon, 1995. p. 1-28.

KERBRAT-ORECCHIONI, C. Le désaccord, réaction "non préférée"? Les cas des débats présidentiels. Cahiers de praxématique, Montpellier, n. 67, 2016, p. 1-20.

KERBRAT-ORECCHIONI, Catherine. Les débats de l'entre-deux-tours des élections présidentielles françaises: constantes et évolutions d'un genre. Paris : L’Harmattan, 2017.

LEECH, G. Principles of Pragmatics. London: Longman, 1983.

LEECH, G. The pragmatics of politeness. Oxford: Oxford University Press, 2014.

PERRIN, L. Polyphonie et autres formes d'hétérogénéité énonciative : Bakhtine, Bally, Ducrot, etc. Pratiques, Paris, n. 123/124, 2004, p. 7-26.

ROULET, E. Stratégies d'interaction, modes d'implicitation et marqueurs illocutoires. Cahiers de Linguistique Française, Genebra, v. 1, p. 80-103, 1980.

ROULET, E. De la nécessité de distinguer des relations de discours sémantiques, textuelles et praxéologiques. In: ANDERSEN, H. L.; NØLKE, H (org.). Macro- syntaxe et macro-sémantique. Bern: Peter Lang, 2002, p. 35-57.

ROULET, E. The description of text relation markers in the Geneva model of discourse organization. In: FISCHER, K. (org.). Approaches to Discourse Particles. Amsterdam: Elsevier, 2006, p. 115-131.

ROULET, E.; FILLIETTAZ, L.; GROBET, A. Un modèle et un instrument d'analyse de l'organisation du discours. Berne: Peter Lang, 2001. 